\title{
An Analysis of Interscholastic Athletic Directors' Religious Values and Practices on Pregame Prayer in Southeastern United States: A Case Study
}

\author{
John J. Miller \\ Troy University \\ Khalil Lee \\ Auburn University \\ Christina L. L. Martin
}

Troy University

\begin{abstract}
Interscholastic athletic directors in eight states throughout the southeastern part of the United States were surveyed to analyze whether their personal religious practices affected their at-work practices and if relationships existed between the athletic directors' religious values and their decisions to promote prayer at high school athletic events. Ninety percent reported that their religious values often or very often influenced their decisions at work. Ninety-three percent revealed that their athletic teams often or very often conducted a team-only pregame prayer, most often led by the head coach. However, more than half allowed public pregame prayer. Additional results indicated positive correlations existing between the frequency the athletic director attended religious services and how often religious practices were applied in their daily lives as well as how often religious values influenced work. A negative correlation revealed a relationship between the possible legal consequences and how often team prayer occurred before/after football games.
\end{abstract}

Interscholastic sports in the United States have held a strong association with Christian religious practices for many years (Coakley, 2004). When attending a high school football game, a player may be seen with tape around his wrist bearing the image of a cross or another religious symbol, or cheerleaders may hold up a football banner with a written Bible verse (Fernandez, 2012). While the influence that religion plays in the sporting context is generally time-honored, conflicts between sports and religion have arisen (Asplund, 2003).

The clash between religion and sports involves the extent that religious integration should be tolerated in public school athletics (Asplund, 2003). Although 
the United States Supreme Court has ruled in Santa Fe High Independent School District v. Doe (2000) and Borden v. East Township School District (2008) that prayers led by coaches or over public address systems at public interscholastic athletic contests are unconstitutional, such occurrences are relatively common, particularly in the southern part of the United States (Gillentine, Goldfine, Phillips, Seidler, \& Scott, 2004). Another study that analyzed prayer at interscholastic athletic events in the United States reported that $50 \%$ of interscholastic high school athletic directors in the South engaged in pregame prayer (Beck, Goldfine, Marley, Seidler, \& Gillentine, 2009). The study also indicated that nearly $25 \%$ in the Midwest and $23 \%$ in the West also allowed pregame prayers. The study also revealed that football was the most likely sport to have a pregame prayer $(40 \%)$, followed by basketball (5\%). Interestingly, fewer than $1 \%$ of the respondents indicated that high school sports other than football or basketball conducted a prayer before a contest (Beck et al., 2009).

This article was written as a case study for several reasons. First, Abercrombie, Hill, and Turner (1984) defined case studies as a "detailed examination of a single example of a class of phenomena, ... which may be tested systematically with a larger number of cases" (p. 34). Case studies may be well suited for pilot studies but not for full-fledged research schemes. Since the focus of this study concentrated on a specific, not a broad population, a case study approach was used. Second, although case studies often cannot be generalized to a larger population, it can help to "form the urban environments in which we live" (Flyvbjerg, 2006, p. 219). Whereas context-independent facts and rules, which are the basis of textbook learning, permit the student to reach the novice rank, carefully selected case studies can assist students in attaining learning proficiency of the subject (Flyvbjerg, 2006). As such, case studies can generate the kind of context-dependent knowledge that can move the student from beginner to authority (Christensen \& Carlile, 2009).

This first part of this case study will describe current issues concerning pregame prayer. The second section will provide a brief explanation of First Amendment components. The third part will identify two cases relating to prayer at sports events. The fourth section will reveal the methodology and results of a survey to determine whether interscholastic athletic directors' religious values play a part in having pregame prayer in the southeastern part of the United States. Discussion of the results and conclusion will be in the fifth section. The final area will advance questions for class research and discussion so that students can place themselves as an athletic director in the context being studied.

In 2012, the Freedom from Religion Foundation, a national state-church watchdog group targeting pregame prayers, has elevated the issue regarding religion and sports. The group distributed letters to high school superintendents and college chancellors in Georgia, Mississippi, and Tennessee protesting the practice of preevent prayers at athletic and other school-sponsored activities (Popke, 2012). Written by the copresidents of Freedom from Religion Foundation the letter stated

... it is illegal for a public school to organize, sponsor, or lead prayers at public high school events. The Supreme Court has continually struck down formal teacher- or school-led prayer in public schools. . . Prayers imposed by schools over loudspeakers at athletic events or other school-sponsored events bear the imprint of the state. (Popke, 2012, para. 2) 
Such a declaration has been met with significant backlash, especially from individuals in the southeastern part of the United States. For example, the director of the Fellowship of Christian Athletes in Tennessee simply stated "Prayer is going to continue to happen" (Popke, 2012, para. 9). However, legal scholars have disagreed about the continuing presence of prayer before a public school athletic contest. For example, while Alexander and Alexander (2000) stated that the Supreme Court had ". . . slammed the door on religion in the public schools" (p. 136), Batista (2002) argued that as long as prayer is perceived as not being sponsored by the school ". . . the Supreme Court and other federal courts have reaffirmed that the First Amendment authorizes and protects students' freedom to engage in religious activities in the public schools" (p. 88).

The pregame prayer debate has also involved a "moment of silence" that is often instituted before athletic contests. In Wallace v. Jaffree (1985) the United States Supreme Court nullified a statute in Alabama that allowed a moment of silence at the start of each school day. The primary reason the Court disallowed the statute was due to an effort by the Alabama legislature to ". . . return voluntary prayer to our public schools ... . with no other purpose in mind" (p. 43). However, it is important to note that in Wallace the Supreme Court did not hold that all moments of silence were unconstitutional, since the goal of the Alabama legislature ". . . to return prayer to the public schools is, of course, quite different from merely protecting every student's right to engage in voluntary prayer during an appropriate moment of silence during the schoolday" (p. 59).

Alexander and Alexander (2000) argued that some public schools have "creatively ignored" (p. 135) court decisions in allowing individuals to perform religious activities while on its' property. As the Freedom from Religion Foundation further asserted, there appears to be a continuance of allowing pregame prayer at interscholastic events in southeastern United States (Popke, 2012). As a result, the question, who might be allowing the persistence of pregame prayer practices, needs to be addressed. For the most part, the athletic director at most, if not all, schools is "responsible for implementing the athletics policies that are established by the powers that be-the state, the school board, and central administration" (Bucher $\&$ Krotee, 1998, p. 136). In addition, due to the large number of students who are involved in sports and the escalating number of duties under their control, interscholastic athletic directors are in a highly influential position (Read, 2000). Thus, this case study is one of the first to quantitatively analyze the potential impact of interscholastic athletic directors' religious values in the implementation of pregame prayer in the southeastern part of the United States.

Since athletics can expose a school to litigation, it is important that all coaches, athletic administrators, and school administrators comprehend the legal system (Doleschal, 2006). As it applies to this case study, athletic directors must be aware of the rulings of the United States Supreme Court as they apply to religious practices at athletic-based events. While previous First Amendment Supreme Court cases have dealt with religious concerns, several cases have alleged the occurrence of improper integration of prayer at public school sports events. Two of these cases, Santa Fe High Independent School District v. Doe (2000) and Borden v. East Township School District (2008), will be discussed as they present two different viewpoints by which litigation could occur. For example, Santa Fe High Independent School District v. Doe (2000) involved the practice of pregame prayers being conducted 
using a public address system. The second case, Borden v. East Township School District (2008), dealt with the issue of having a head coach, as a public employee, lead a pregame prayer.

\section{First Amendment Sport-Related Litigation Cases}

\section{Santa Fe High Independent School District v. Doe (2000)}

In the case of Santa Fe High Independent School District v. Doe (2000), the families of two Santa Fe High School (Santa Fe, TX) students protested the practice of prayers being conducted over the high school stadium's public address system before every varsity football game. Before 1995, the Santa Fe School District allowed a high school student council chaplain to offer a prayer at each home football game using the public address system (Santa Fe High Independent School District v. Doe, 2000). The school district provided several explanations for having prayer at football games, such as to solemnize the event, to promote good sportsmanship and student safety, and to establish the appropriate environment for competition (Santa Fe High Independent School District v. Doe, 2000). While the suit was pending, the Santa Fe School District implemented a different policy that sanctioned two student elections. The first election identified the invocations to be given at games. The second election recognized a spokesperson to deliver the invocations. The District Court entered an order to modify the policy to permit only nonsectarian, nonproselytizing prayer. However, the United States Supreme Court stated that the

... election mechanism established by the District undermines the essential protection of minority viewpoints. Such a system encourages divisiveness along religious lines and threatens the imposition of coercion upon those students not desiring to participate in a religious exercise. Simply by establishing this school-related procedure, which entrusts the inherently nongovernmental subject of religion to a majoritarian vote, a constitutional violation has occurred. (Santa Fe High Independent School District v. Doe, 2000, p. 317)

In the decision, the U.S. Supreme Court referred back to a previous ruling which stated that "... adolescents are often susceptible to pressure from their peers towards conformity, and that the influence is strongest in matters of social convention" (Lee v. Weisman, 1992, p. 593). As a result, the Supreme Court ruled that the policy was ". . . invalid on its face because it establishes an improper majoritarian election on religion, and unquestionably has the purpose and creates the perception of encouraging the delivery of prayer at a series of important school events (Santa Fe High Independent School District v. Doe, 2000, p. 317).

While organized prayer in public schools is virtually nonexistent (Fried \& Bradley, 1994), a prevalent method used to instill values into interscholastic athletes, particularly football players, is through prayer (Grossfeld, 2006). According to Grossfeld (2006), more than 50\% of all interscholastic football coaches participated in some sort of prayers with their players. Often this practice takes place because there are few, if any, complaints (Fried \& Bradley, 1994; Price, 2008). However, in one case a complaint was lodged pertaining to the issue of pregame prayer lead by a head coach. This case will be presented in the next section. 


\section{Borden v. East Township School District (2008)}

Borden, a Christian and head high school football coach for 23 years, usually conducted pregame prayer activities by bowing his head, as a silent act, while taking a knee in the locker room during the team's pregame grace (Borden v. East Township School District, 2008). Before Borden became the head football coach, a local minister said a premeal prayer (Borden v. East Township School District, 2008). According to statements in the case, after Borden became the head coach, the school's athletic director told Borden that the minister had to discontinue saying the prayer. As a remedy, the minister wrote a prayer that the student-athletes took turns reading. When the minister retired six years later, Borden did not persist in having the student-athletes continue reading the prayer. Instead, Borden began to read the prayer before the first pregame meal for three seasons, from 2003-2005. In addition, Borden led his team in prayer before each game by having all coaches and athletes take a knee while often reciting

Dear lord, please guide us today in our quest in our game, our championship. Give us the courage and determination that we would need to come out successful. Please let us represent our families and our community well. Lastly, please guide our players and opponents so that they can come out of this game unscathed, [and] no one is hurt. (Borden v. East Township School District, 2008, p. 160)

While these actions were conducted without issue for 23 years of Borden's head football coaching career, in October 2005 several parents complained to the superintendent of the school district that it was inappropriate for a person in Borden's position to lead a team in prayer (Borden v. East Township School District, 2008). Despite the school's athletic director informing him to cease leading the team in prayer, Borden continued doing so at the pregame meals and immediately before a game. If anyone had an issue with the prayers, Borden suggested that they could wait in a nearby restroom until it was over. Eventually, the school district counsel developed guidelines on faculty participation in student prayer.

After receiving the guidelines, Borden resigned. Approximately 10 days later he withdrew his lawsuit and promised to abide with the policy guidelines for the remainder of the season. However, in November 2005, Borden again filed litigation against the school district, the board of education, and the superintendent of the school district (Borden v. East Township School District, 2008).

At first, Borden succeeded at the district court level (Borden v. East Township School District, 2008). However, the case was reversed by the Third Circuit and after certiorari was denied by the U.S. Supreme Court in 2009 (Borden v. School District, 2009), Borden, as a public school employee, was not allowed to conduct pregame team prayer, nor was he allowed to bow his head and pray while down on one knee during a student-led team prayer as it would be a violation of the Establishment Clause. To gain a better understanding, the Establishment Clause of the First Amendment will be discussed next.

\section{The Establishment Clause}

In addressing issues dealing with prayer at interscholastic contests, the major focus involves the First Amendment of the United States Constitution as well as the 
Establishment Clause and the Free Exercise Clause. It is important to consider that in both the Borden $(2008 ; 2009)$ and Santa Fe (2000) cases the courts, including the Supreme Court, used the Establishment Clause. In Santa Fe, the respondents of the lawsuit were Mormon and Catholic students or alumni and their mothers who filed a suit challenging this practice as a violation of the Establishment Clause of the First Amendment (Santa Fe High Independent School District v. Doe, 2000). In Borden, the Third Circuit heavily scrutinized and applied the Establishment Clause to the issue of pregame prayer.

The First Amendment states that "Congress shall make no law respecting an establishment of religion, or prohibiting the free exercise thereof" (U.S. Constitution, Amendment I). It is noteworthy that the first section of the First Amendment is referred to as the Establishment Clause whereas the second part is known as the Free Exercise Clause (Nowak, Rotunda, \& Young, 1983). Although under certain circumstances, the two clauses may intersect, they prevent two very dissimilar types of governmental encroachment on religious freedom (Engel v. Vitale, 1962). However, it is most often through the invocation of the Establishment Clause that prayers at public school athletic contests have been used in litigation (Asplund, 2003).

Alexander and Alexander (2000) identified one of the primary issues under the Establishment Clause as the separation of church and state in the field of public education. Moreover, in McDaniel v. Paty (1978), the United States Supreme Court stated that ". . . the Establishment Clause does not license government to treat religion and those who teach or practice it, simply by virtue of their status as such, as subversive of American ideals and therefore subject to unique disabilities" (p. 641). While the major emphasis of the Establishment Clause is to guard religious liberty, it does not bar all religious activity in public schools (Engel v. Vitale, 1962).

The United States Supreme Court has recognized three separate tests to establish whether governmental action infringes on the Establishment Clause. The three tests are the Lemon Test, the coercion test, and the endorsement test. To further understand the application of the Establishment Clause, a brief explanation of each of the tests will be presented in the next sections.

\section{The Lemon Test}

The Lemon test is necessary to assist in determining "whether a government action violates the Establishment Clause of the First Amendment" (Blackman, 2010, p. 351). Specifically, the Lemon test is a three-prong test indicating that the program and/or statute 1) must have a nonreligious purpose, 2) does not promote or hinder religion, and 3) must not foster excessive governmental entanglement with religion (Blackman, 2010). A violation of any one of these parts is likely to result in a program and/or statute being interpreted as unconstitutional or in violation with First Amendment protections.

\section{The Endorsement Test}

The endorsement test relates to circumstances in which the state partakes in an activity that has direct connotations to a religion (Sante Fe v. Doe, 2008). In addition, the endorsement test may be ascertained by a "reasonable observer familiar with the history and context of the display" when that observer perceives "the display as a government endorsement of religion" (Modrovich v. Allegheny County, 2004, 
p. 401). For example, people representing a state entity as employees violate the concept of religious endorsement when they bow their heads or take a knee with their teams (Borden v. East Township School District, 2008). In the Borden (2008) case, since the coach was identified as a state actor, the court ruled that the state was represented in a religious activity.

\section{The Coercion Test}

The coercion test questions whether the students were coerced or pressured into participation. The coercion test is often employed in school prayer cases because it has been asserted that the environment within a school proficiently lends itself to applying "subtle coercive pressures" on students (Lee v. Weisman, 1992). The coercion test necessitates analyzing the effect the school's action may have had in coercing someone, such as a student, into supporting or participating in religion (Hyndman, 2005).

The religious rights protected by the Constitution are considered to be breached when public school administrators support a distinct religious practice of prayer (Engel v. Vitale, 1962). Although the athletic director in the Borden case appeared to act appropriately by instituting means to protect against the perception of religious infringement, Gillentine, Goldfine, Phillips, Seidler, and Scott (2004) have reported that more than $95 \%$ of the high school athletic departments in their study did not have any written policies concerning prayer and/or religious activities. Moreover, it has been noted that prayers being led by school officials at interscholastic athletic events occur often, especially in the southeastern United States (Beck, Goldfine, Marley, Seidler, \& Gillentine, 2009).

\section{Purpose of the Study}

It is clear from the transpiration of previous lawsuits, the studies by Gillentine et al. (2004) and Beck et al. (2009), as well as the recent activities regarding the Freedom from Religion Foundation (Popke, 2012), that prayer at public school-sponsored athletic events is a relevant issue, yet quantitative research still remains limited in this area. Thus, this study sought to add to the existing literature of Gillentine et al. (2004) and Beck et al. (2009) by determining 1) the athletic director's personal and at-work religious practices and 2) if relationships existed between the athletic directors' religious values and their decisions to promote prayer at high school athletic events in the southeastern United States.

\section{Methodology}

\section{Questionnaire Instrument}

A 16-item questionnaire consisting of eight demographic and eight Likert-scale $(0=$ not at all; $1=$ rarely; $2=$ often; $3=$ very often $)$ questions was developed by the researchers. It has been suggested that by incorporating different methods of answering a survey, the truthfulness of the answer may increase (Patten, 2000). For example, the respondent cannot simply check the same answers to all the statements. Since a method regarding the presence or absence of more than one 
criterion was going to represent the traits of interest, criterion-related validity was calculated. One of the most efficient ways to test for criterion-related validity is to administer the instrument to a group of experts who are known to exhibit the trait to be measured (Carmines \& Zeller, 1979). A wide range of items may be developed for the questionnaire as invalid questions would be eliminated after the control group has taken it. Acting as the control group, four unbiased intercollegiate athletic directors were shown 35 statements in the questionnaire. After this initial phase, the responses were analyzed and nine statements were deemed inconsistent or not important. The nine statements were then culled from the questionnaire. The panel of experts reviewed the questionnaire and unanimously approved the remaining statements.

The next step was to determine the reliability of the instrument. Reliability addresses the consistency of the research findings in quantitative research (Litwin, 1995). One of the most used ways to determine the reliability of empirical measurements is by the retest method in which the same test is given to the same people after a period of time (Litwin, 1995). The reliability of the test (instrument) can be estimated by examining the consistency of the responses between the two tests. To ensure that the survey questionnaire was reliable, five high school athletic directors, who were not in the regions in this study, were asked for their input. The result of the pilot study was $\alpha=.82$ which is above the criteria to establish reliability (Patten, 2000).

\section{Participants}

The states identified in this region included Alabama, Florida, Georgia, Kentucky, Mississippi, North Carolina, South Carolina, and Tennessee. A list of every public high school in each state was attained via an accepted online source (Public school review, 2012a-h). High schools on the website were classified by county for each state, and each school contained its front office contact information. Participants were randomly selected from states in the southeastern part of the United States based on the United States Environmental Protection Agency definition (About EPA region 4 southeast, 2011). To ensure that each county had a chance for representation, one out of every ten schools in the state had a chance for representation. As a result of the sampling technique, the investigators distributed the online questionnaire via Survey Monkey to 438 interscholastic athletic directors.

Even though responses may have been received, the investigator sent a reminder to all identified schools two weeks following the initial distribution of the questionnaire. The reason for sending them to all parties was that the investigators did not have any knowledge as to who responded due to the anonymity protocols put into place. All of the potential respondents were notified in writing on the questionnaire that participation in the study was completely voluntary and there would be no penalties for choosing not to participate. Further, they were informed that they would be able to withdraw at any time, for any reason, without penalty. Nowhere on the questionnaire did the respondents need to either identify themselves or their specific high school name.

Each participant was asked to voluntarily complete a survey comprised of questions pertaining to personal religious values. Thirty (7\%) fully completed the questionnaire. Although the response rate for this study was low, Cook, Heath, and Thompson (2000) stated that "a sample of fewer than $1 \%$ of the population can be more representative, indeed much more representative, than a sample of $50 \%$ 
or $60 \%$ of the population" (p.821). Krosnick (1999) also stated that ". . . surveys with very low response rates can be more accurate than surveys with much higher response rates" (p. 540). While potential reasons for the low response rate are provided in the limitations section of this study, because the intent of the investigation was to develop a case study and not meant to be generalized, the investigators felt comfortable in proceeding with the study.

Descriptive statistics, such as frequencies and percentages, were used in the study. Further, a Pearson's correlation analyses was used to measure the strength of an association between the athletic directors' religious values and religious practices and their decisions relating to prayer at high school athletic events in the southeastern United States. The level of significance was set at .05.

\section{Results}

\section{Respondent Demographic Information}

The demographic results (see Table 1) indicated that $17(57 \%)$ of the respondents possessed a Master's level education while $10(33 \%)$ had attained a bachelor's degree. In terms of years of experience, $20(67 \%)$ indicated that they had been an athletic director for more than 15 years. When asked about their personal religious affiliation, 27 (90\%) revealed that they were Christians. In regards to school location, $23(77 \%)$ indicated that they were in a rural community. In addition, 20 $(67 \%)$ reported that the population of their school was between 500-1500 students. Finally, $23(77 \%)$ of the respondents indicated that there was not a school policy regarding prayer at community events.

\section{Athletic Director's Personal and At-Work Religious Practices}

As exhibited in Table 2, $26(86 \%)$ of the athletic directors perceived that they applied religious values often or very often in their daily life. Twenty-four (80\%) reported that they often or very often attended religious services on a weekly basis. Finally, 27 (90\%) reported that their religious values often or very often influenced their decisions at work.

Twenty-eight $(93 \%)$ revealed that their athletic teams often or very often conducted a team-only pregame prayer. Sixteen (53\%) indicated that the head coach lead the team pregame prayer often or very often. When asked about public pregame prayer, $19(63 \%)$ reported that spectators were rarely or never included. Moreover, $26(90 \%)$ did not have a pregame prayer led by a school official or denominational figure (i.e., priest, pastor, reverend, rabbi, cleric, etc.). Interestingly, 21 (70\%) of the respondents rarely, if ever, considered the legal consequences of conducting a pregame prayer.

\section{Relationship Athletic Directors' Religious Values to Prayer at Athletic Contests}

The Pearson's $r$ correlation analyses revealed a number of significant correlations emerged between athletic directors' religious values and questions designed to address decisions to pray at high school football games. First, a direct or positive correlation $[r(27)=.65, p<.001]$ existed between how often the athletic director 
Table 1 Respondent Demographic Information

\begin{tabular}{lcc}
\hline Item & $\boldsymbol{n}$ & $\%$ \\
\hline Education level & 1 & 3 \\
Associate's degree & 10 & 33 \\
Bachelor's degree & 17 & 57 \\
Master's degree & 2 & 7 \\
Terminal degree & & \\
Years of experience & 3 & 10 \\
0-5 years & 2 & 7 \\
6-10 years & 4 & 13 \\
11-15 years & 20 & 67 \\
More than 15 years & & \\
Religious affiliation & 27 & 90 \\
Christian & 1 & 3 \\
Other & 2 & 7 \\
None & & \\
Type of school & 7 & 23 \\
Urban & 23 & 77 \\
Rural & & \\
School population & 23 & 67 \\
501-1500 & 4 & 13 \\
1501-2500 & 1 & 37 \\
2501-3500 & & \\
School policy on prayer & 23 & \\
Yes & & \\
No & & \\
\hline & & \\
\hline
\end{tabular}

Table 2 Athletic Director's Personal and At-Work Religious Practices

\begin{tabular}{|c|c|c|c|c|c|c|c|c|}
\hline \multirow[b]{2}{*}{ Item } & \multicolumn{2}{|c|}{ Not at all } & \multicolumn{2}{|c|}{ Rarely } & \multicolumn{2}{|c|}{ Often } & \multicolumn{2}{|c|}{ Very often } \\
\hline & $n$ & $\%$ & $n$ & $\%$ & $n$ & $\%$ & $n$ & $\%$ \\
\hline Applied religious values at work daily & 1 & 3 & 2 & 7 & 9 & 30 & 17 & 57 \\
\hline Attended religious on a weekly basis & 2 & 7 & 4 & 13 & 10 & 33 & 14 & 47 \\
\hline $\begin{array}{l}\text { Religious values influenced decisions } \\
\text { at work }\end{array}$ & 1 & 3 & 2 & 7 & 13 & 43 & 14 & 47 \\
\hline Athletic teams conduct pregame prayer & 1 & 3 & 1 & 3 & 12 & 40 & 16 & 53 \\
\hline Pregame prayer lead by a head coach & 5 & 17 & 8 & 27 & 11 & 37 & 5 & 17 \\
\hline $\begin{array}{l}\text { Pregame prayer lead by denomina- } \\
\text { tional person (priest, rabbi, cleric, etc.) }\end{array}$ & 12 & 40 & 15 & 50 & 1 & 3 & 2 & 7 \\
\hline Pregame prayer included spectators & 15 & 50 & 4 & 13 & 4 & 13 & 7 & 23 \\
\hline $\begin{array}{l}\text { Legal consequences are considered to } \\
\text { conduct pregame prayer }\end{array}$ & 9 & 30 & 12 & 40 & 4 & 13 & 4 & 13 \\
\hline
\end{tabular}


attended religious services and how often religious practices were applied in their daily lives. A second direct correlation $[r(28)=.79, p<.001]$ existed between how often the athletic directors attended religious services and how often religious values influenced work. A third direct correlation $[r(27)=.74, p<.001]$ emerged between how often the athletic directors applied their religious practices in daily life and how often religious values influenced their work. A fourth correlation $[r(28)=.36$, $p<.05$ ] revealed that a relationship existed between the rural location of the school and conducting public pregame prayer before football games. Finally, a negative or indirect correlation $[r(27)=-.54, p<.01]$ was revealed between how often possible legal consequences were considered by the athletic director and how often team prayer occurred before/after football games.

\section{Discussion}

Although many may associate pregame prayer to a large public invocation before the start of a contest, it is interesting to note that overall more than $60 \%$ did not conduct pregame prayer (including moments of silence) in front of spectators and $90 \%$ did not have a pregame prayer led by a denominational figure (i.e., priest, pastor, reverend, rabbi, cleric, etc.). As a result, there would be no violation of First Amendment rights for that population. However, despite the Supreme Court rulings in the Santa Fe v. Doe (2000) and Borden v. East Township School District (2008), more than $90 \%$ of the respondents indicated that their teams participated in team only pregame prayer, of which more than 50\% acknowledged that team pregame prayer was led by the head coach. The question then becomes why are athletic directors, particularly in the southern part of the United States, allowing pregame prayers to be led by coaches despite the rulings of the United States Supreme Court?

One potential reason for allowing coaches to lead team-only pregame prayer is that nearly $80 \%$ responded that their school did not have a policy concerning prayer at open events. In addition, positive correlations indicated that the athletic directors' religious values influenced their work on a daily basis and a negative correlation appeared between the consideration of legal consequences and pregame prayer permission. Stated another way, the majority of athletic directors did not perceive the need to address pregame prayer as a policy. Secondly, athletic directors who responded to the questionnaire may exert the religious values in allowing pregame prayer because of the lack of complaints from the community. Since $90 \%$ of the respondents indicated that they were Christians, it would make intuitive sense that the prayers offered before a contest originated in that faith. However, by bringing and applying their religious values to their workplace, the athletic directors may be violating the coercion and endorsement tests. This result may be exemplified by a comment from a school superintendent who stated that "for generations, [pregame prayer] is a practice that's been followed throughout the South" (Popke, 2012, para. 3). According to Doughtery, Goldberger, and Carpenter (2002), "Religious practices, such as prayer in schools, might affect another person with the strength of coercion" (p. 66). In Lynch v. Donnelly (1984), the Supreme Court stated that the "government may not coerce anyone to support or participate in religion or its exercise" (p. 577). If the foundation of such coercion resides with the athletic directors, as state actors, they would be in violation of the First Amendment (Dougherty et al., 2002). 
The athletic directors may also be in violation of the endorsement test. Specifically, the correlations revealed significant relationships between how often the athletic directors attended religious services and how often religious values influenced work as well as how often the athletic directors applied their religious practices in daily life and how often religious values influenced their work. If athletic directors allow pregame prayer because it followed their personal religious values, a person with knowledge of such participation could reasonably believe that the school would be endorsing religion and not simply showing respect to others' observance (Borden v. East Township School District, 2008).

An additional part of the answer may lie in the location of the schools in which respondents resided. For example, almost $80 \%$ indicated that they were located in a rural community. Although the majority of respondents did not conduct public pregame prayer, a relationship emerged between the rural location of the school and conducting both team and public pregame prayers. Perhaps it is this acceptance of a pregame prayer that precludes any complaints from the general community, because more than $90 \%$ of the respondents identified themselves as Christian. In addition, previous studies have reported that rural populations in the southern United States relied on Christian religious beliefs and practices (Mitchell \& Weatherly, 2000; Yoon \& Lee, 2004).

It appears that the decision to allow pregame prayer in this study is value-based by the athletic directors who responded to the survey. As mentioned previously, interscholastic athletic directors are often in a position of influence (Read, 2000). Because of the confusion and ". . . vagueness of the standards articulated by the Supreme Court" (Helman, 2008, p. 379) concerning pregame prayer, legal complications arise without the athletic directors possessing adequate knowledge of the First Amendment and the Establishment Clause. Regardless of their personal beliefs, an athletic director should try to refrain from exerting their religious values onto the population they most influence, such as coaches and athletes. They must be aware that they are responsible for a diverse group of individuals that include coaches and athletes who are in attendance at team pregame meetings as well as spectators at athletic contests.

\section{Limitations}

Although efforts were made to obtain a random and representative sample, the response rate was less than desired. Several attempts were made to collect data of the nonrespondents to no avail. Therefore, the findings are limited to those who participated in the study. One significant limitation was the relatively low response rate. Several reasons may explain why the response rate was low. First, the survey may have been perceived as junk mail. In 2004, an internet security firm reported that $76 \%$ of the emails sent to clients were screened as spam. Another reason for the low response rate may have been perceived privacy and security issues. The concerns fall into two categories: the security of transmissions and how data will be used (Berry, 2004). Many respondents may have wondered if their answers will be treated confidentially, especially considering the sensitivity of the research topic. As in many survey-based research studies, it can only be assumed that the individuals responded in a truthful and honest fashion and the responses do not reflect a measure of bias from their own personal perceptions. In addition, respon- 
dents may have held strong religious convictions but chose not to reveal them due to concerns for privacy.

\section{Future Research}

This study was not conducted to provide a comprehensive analysis of how high schools in the southeastern part of the United States address the issue of pregame prayer. Rather, this case study did generate some interesting results to be considered for future research. For example, the majority allowed coaches to lead teams in pregame prayer but seemed reticent in allowing denominational figures to do so. As a result, future research could analyze interscholastic athletic director's knowledge of the First Amendment practices as it applies to pregame prayer. Previous investigations that have been conducted have centered on the southern part of the United States. As such, future studies could be expanded to determine pregame prayer practices in other regions of the country. Finally, recent allegations levied by the Freedom from Religion Foundation included the practices of pregame prayer at intercollegiate as well as interscholastic athletic events (Popke, 2012), and reports have surfaced that pregame prayer is becoming a potential issue in youth sports (Foxnews.com, 2010). Future research could incorporate the questions raised in this study to include intercollegiate and youth sports.

\section{Conclusion}

Dent (1993) stated that numerous people perceive that the "... government is hostile to their religion, especially in the public schools" (p. 707). Annie Laurie Gaylor, copresident of the Freedom from Religion Foundation, stated that public prayer promotes Christianity since the prayers often end "in Jesus' name" (as cited in Boucher, 2012). In an interview, Gaylor stated that "We are not a Christian nation, this is not a Christian school district. Football games . . . are not Christian football games" (Boucher, 2012, para. 4). However, it is important to note that although most people may associate violations of the Establishment Clause to impact Christian prayer, the United States Supreme Court held that a prayer led by a rabbi during a middle school graduation ceremony also violated the Establishment Clause (Lee v. Weisman, 1992).

Due to the significance that is placed on religion and freedoms afforded by the First Amendment, it is foreseeable that social conflict would occur. Coakley (2004) indicated that the issue of religion in sports will continue to provide social conflict as the role of religion often appears to promote the values of one person or group at the expense of all others. Since ambiguity has clouded the issue regarding prayer at public high school athletic contests, most notably in football, it is incumbent on high school athletic directors to be continually aware of each interpretation by the Supreme Court.

Although most parents might not have any issues with pregame prayers being led by the head coach or a specific religious representative, those in the religious minorities might have a problem with such exercise. The First Amendment was intended to protect the rights of these minorities (Fried \& Bradley, 1994). Without an awareness of the Supreme Court rulings, athletic directors will create an environment in which the social conflict between prayer and the fields of athletic competition sponsored by public high schools will continue to be decided in courts of law. 


\section{Case Study Discussion Questions}

1. The United States Supreme Court has recognized three separate tests to establish whether governmental action infringes on the Establishment Clause. The three tests are the coercion test, the Lemon test, and the endorsement test. Research each of these tests and explain how they may be applied to pregame prayer at interscholastic, intercollegiate, and/or professional sport contests.

2. Prayer in a sport setting can be different from the prayer offered at a high school graduation. Conduct research to explain why and how.

3. According to sport sociologist Jay Coakley, the role of religion in sport often focuses on the progression of the religious values of a person to the detriment of others. Explain how the findings of this study may perpetuate Coakley's contention.

4. The Freedom from Religion Foundation specifically targeted public institutions in the southern United States. List and explain three reasons why the other regions of the United States were not sought out.

5. Imagine yourself as a new athletic director at a public high school where it is accepted that coaches conduct pregame prayers. How would you address this situation? Explain your rationale.

\section{References}

Abercrombie, N., Hill, S., \& Turner, B.S. (1984). Dictionary of sociology. Harmondsworth, UK: Penguin.

Alexander, F., \& Alexander, R. (2000). From the gridiron to the United States Supreme Court: Defining the boundaries of the first amendment's establishment clause. Journal of Legal Aspects of Sport, 10(3), 129-137.

Asplund, B. (2003). First Amendment-Establishment Clause-Student-led, student-initiated prayer at football games violates the Establishment Clause-Santa Fe Independent School District v. Doe, 530 U.S. 290 (2000). Seton Hall Journal of Sport Law, 13, 97-174.

Batista, P.J. (2002). Balancing the First Amendment's Establishment and Free Exercise Clauses: A rebuttal to Alexander \& Alexander. Journal of Legal Aspects of Sport, 12, $87-116$.

Beck, J., Goldfine, B., Marley, S., Seidler, T., \& Gillentine, A. (2009). Prayer at interscholastic athletic events in the United States: A regional analysis [Abstract]. Retrieved from http://www.nassm.com/files/conf_abstracts/2009-077.pdf.

Berry, D.M. (2004). Internet research: Privacy, ethics and alienation: an open source approach. Internet Research, 14(4), 323-332. doi:10.1108/10662240410555333

Blackman, J. (2010). This lemon comes as a lemon: The Lemon Test and the pursuit of a statute's secular purpose. George Mason University Civil Rights Law Journal, 20, 351-415.

Borden v. School District of East Brunswick, 523 F.3d 153, 3d Cir. N.J. 2008.

Borden v. School District of East Brunswick, 555 U.S. 1212, 2009.

Boucher, D. (2012). Protests follow ban on pre-game prayer. Daily Mail. Retrieved from http://www.dailymail.com/News/201209230170.

Bucher, C.A., \& Krotee, M.L. (1998). Management of physical education and sport (11th ed.). Boston: McGraw Hill.

Carmines, E.G., \& Zeller, R.A. (1979). Reliability and validity assessment. Beverly Hills, CA: Sage Publishing. 
Christensen, C.M., \& Carlile, P.R. (2009). Course research: Using the case method to build and teach management theory. Academy of Management Learning \& Education, 8(2), 240-251. doi:10.5465/AMLE.2009.41788846

Coakley, J.J. (2004). Sport and religion: Is it a promising combination? In J.J. Coakley (Ed.) ( $8^{\text {th }}$ ed.) Sport in society: Issues and controversies (pp. 526-563). New York: McGraw- Hill.

Cook, C., Heath, F., \& Thompson, R.L. (2000). A meta-analysis of response rates in Web or Internet-based surveys. Educational and Psychological Measurement, 60, 821-836. doi:10.1177/00131640021970934

Dent, G.W., Jr. (1993). Religion and the public schools after Lee v. Weisman: Of God and Caesar: The free exercise rights of public school students. Case Western Reserve Law Review, 43(3), 707-752.

Doleschal, J.K. (2006). Managing risk in interscholastic athletic programs: 14 legal duties of care. Marquette Sports Law Review, 17, 295-339.

Dougherty, N., Goldberger, A.S., \& Carpenter, L.J. (2002). $1^{\text {st }}$ Amendment issues in sport and physical activity. In N. Dougherty, A.S. Goldberger, \& L.J. Carpenter (Eds.), Sport, physical activity, and the law (3rd ed., pp. 63-78). Champaign, IL: Sagamore Publishing.

Engel v. Vitale, 370 U.S. 421, (1962).

Fernandez, M. (2012). Texas judge, siding with cheerleaders, allows Bible verses on banners at school games. The New York Times. Retrieved from http://www.nytimes. com/2012/10/19/us/court-says-texas-cheerleaders-can-use-bible-verses.html.

Flyvberg, B. (2006). Five misunderstandings about case-study research. Qualitative Inquiry, $12,219-245$.

FoxNews.com. (2010, September 29). Pregame prayers at Pee Wee football games are out of bounds, Florida dad says. Retrieved from http://www.foxnews.com/us/2010/09/29/ florida-parent-protests-prayer-ritual-football- games/\#ixzz2AyhJ70mI.

Fried, G., \& Bradley, L. (1994). Applying the First Amendment to prayer in a public university locker room: An athlete's and coach's perspective. Marquette Sports Law Review, 4(2), 301-321.

Gillentine, A., Goldfine, B., Phillips, D., Seidler, T., \& Scott, D. (2004). Prayer at athletic events. Strategies, 18(1), 13-15. doi:10.1080/08924562.2004.10591108

Grossfeld, S. (2006, November 7). An issue of fair pray: Disagreement sends coach, school to court. Boston Globe, D1.

Helman, E. (2008). Borden v. East Brunswick School District: Clarifying First Amendment jurisprudence in the public school context. New England Law Review, 42, 363-386.

Hyndman, M. (2005). Tradition is not law: Advocating a single determinative test for Establishment Clause cases. Marshall Law Review, 31, 101-136.

Krosnick, J. (1999). Survey research. Annual Review of Psychology, 50, 537-567. doi:10.1146/annurev.psych.50.1.537

Lee v. Weisman, 505 U.S. 577 (1992).

Litwin, M.S. (1995). How to measure survey reliability and validity. Thousand Oaks, CA: Sage Publications.

Lynch v. Donnelly, 465 U.S. 668, 690-92 (1984).

McDaniel v. Paty, 435 U.S. 618 (1978).

Mitchell, J., \& Weatherly, D. (2000). Beyond church attendance: Religiosity and mental health among rural older adults. Journal of Cross-Cultural Gerontology, 15, 37-54. doi:10.1023/A:1006752307461

Modrovich v. Allegheny County, 385 F.3d 397, 2004 U.S. App. LEXIS 20875 (3d Cir. Pa. 2004).

Nowak, J., Rotunda, R., \& Young, J. (1983). Constitutional law. St. Paul, MN: Thomson-West.

Patten, M.L. (2000). Judgmental-empirical validity. In M. L (Ed.), Understanding research methods ( $2^{\text {nd }}$ ed.) (pp. 61-64). Los Angeles, CA: Pyrczak Publishing. 
Popke, M. (2012). Pregame prayers under attack at high schools, colleges. Athletic Business. Retrieved from http://www.athleticbusiness.com/editors/blog/default.aspx?id=939.

Price, A.E. (2008). Understanding the free speech rights of public school coaches. Seton Hall Journal of Sports and Entertainment Law, 18, 209-254.

Public School Review. (2012a). Alabama public schools. Retrieved from http://www.publicschoolreview.com/public_schools/stateid/AL.

Public School Review. (2012b). Florida public schools. Retrieved from http://www.publicschoolreview.com/public_schools/stateid/FL.

Public School Review. (2012c). Georgia public schools. Retrieved from http://www.publicschoolreview.com/public_schools/stateid/GA.

Public School Review. (2012d). Kentucky public schools. Retrieved from http://www.publicschoolreview.com/public_schools/stateid/KY.

Public School Review. (2012e). Mississippi public schools. Retrieved from http://www. publicschoolreview.com/public_schools/stateid/MS.

Public School Review. (2012f). North Carolina public schools. Retrieved from http://www. publicschoolreview.com/public_schools/stateid/NC.

Public School Review. (2012g). South Carolina public schools. Retrieved from http://www. publicschoolreview.com/public_schools/stateid/SC.

Public School Review. (2012h). Tennessee public schools. Retrieved from http://www. publicschoolreview.com/public_schools/stateid/TN.

Read, D. (2000). Going pro: The proliferation of professional sport leagues is giving more athletes great dreams of a pro career. It's also giving high school and college athletic directors a new challenge. Athletic Management, 12(3), 20-27.

Santa Fe Independent School District v. Doe, 503 U.S. 290 (2000).

United States Constitution, Amendment I.

United States Environmental Protection Agency. (2011). About EPA region 4 southeast. Retrieved from http://www.epa.gov/aboutepa/region4.html.

Wallace v. Jaffree, 472 U.S. 38 (1985).

Yoon, D.P., \& Lee, E.K.O. (2004). Religiousness/spirituality and subjective well-being among rural elderly Whites, African-Americans, and Native Americans. Journal of Human Behavior in the Social Environment, 10(1), 191-211. doi:10.1300/J137v10n01_05 